\title{
Interest Group Support and Electoral Success in the Swiss Elections of 2015. A Candidate Survey Analysis
}

\author{
Georg Lutz ${ }^{1}$, André Mach ${ }^{2}$ and Riccardo Primavesi ${ }^{2}$ \\ ${ }^{1}$ FORS, University of Lausanne \\ ${ }^{2}$ IEPHI, University of Lausanne
}

\begin{abstract}
Politicians, parties and interest groups are strongly interlinked in Switzerland. Most studies focus on the interest group influence during parliamentary legislative processes. This article fills a gap by focusing on a question that was largely ignored so far: the impact of interest group support on electoral success of candidates. We collected information on the magnitude and nature of self-reported relations between individual candidates and many interest groups in the 2015 Swiss national election. This new and unique data set allows us to explore the varying impact of specific interest group types on candidates electoral success. Being endorsed by many interest group and occupying leading positions are positively correlated with larger shares of preference votes, while financial contribution show no significant impact. There is, however, variation how endorsements by and leading positions at interest group matter for candidates from different parties depending on the type of interest group.
\end{abstract}

\section{Introduction ${ }^{1}$}

Parties and candidates are not the only actors in electoral politics. Elections are crucial moments to determine the general path of future policy making and therefore different interest groups seek influence during elections. However, seeking influence is not a oneway street; interest groups, parties and candidates have mutual interests. Interest groups want to help candidates and parties who share their political agenda to be elected to parliament. Parties and candidates need support from interest groups to obtain votes. Therefore, relationships between parties, candidates and interest groups have not only historically been of great importance but are still highly relevant.

This paper focuses on the support of interest groups for individual candidates and its impact on electoral success, measured as the number of preference votes candidates receive. The possible influence of interest groups in the electoral context has remained largely neglected in modern democracies (except for in the U.S., where the topic is widely debated; see below). In Switzerland, there has been relatively little scholarly interest in this

\footnotetext{
${ }^{1}$ This paper is part of a research project funded by the Swiss National Science Foundation entitled "Networks or Good Campaigns? Electoral Success of Swiss Candidates in the 2015 Elections" (No. 159338) and directed by Georg Lutz and André Mach. We thank the guest editors, Marc Bühlmann, Denise Traber and Pascal Sciarini, for their comments during the preliminary workshop, as well as the two anonymous reviewers who contributed to clarify our paper substantially. A special thanks goes to Steven Eichenberger for his invaluable tips, continuous review and proofreading.
} 
topic (with the exception of Gruner et al. 1975, even though the analysis is not very detailed in this article). This neglect is surprising since in Switzerland, interest groups are generally considered central political actors in the representative and the direct democratic decision making process. International studies dealing with the links between political parties and interest groups also rarely specifically address the question of interest groups' involvement in electoral campaigns (see Allern and Bale 2012; Farrell and Schmitt-Beck 2008; Rasmussen and Lindeboom 2013). One of the reasons may be that support from interest groups is not the only factor explaining the electoral success of individual candidates. Other elements, such as campaign spending, the use of different campaign instruments, a convincing message or simple cues, such as incumbency, play an important role in many elections. Other structural social and political dynamics unrelated to campaigning are highly relevant as well.

In this article, we focus on candidates running for elections because they are crucial actors linking the represented and representatives. Candidates present their views to voters independent of the parties and candidates earn a mandate based on their political profile and on what they represent. The shift in recent years to examine individual candidates beyond the voter-party link has several justifications. First, parties are not uniform actors but consist of individuals with different views, roles, incentives, intentions and beliefs, both within and between parties. Interest groups also do not just interact with parties; they mainly establish direct relationships with individuals (Erne and Schief 2016). Second, candidates are central in the representation process. Candidates act as intermediaries between voters, parliaments and governments and they play a central role in electoral campaigns, too. Parliaments also consist of individuals with their own preferences, which may at least partially deviate from the party line. Third, there is a trend toward personalization during elections. Election campaigns often focus on top candidates instead of the party profile at large. This personalization of campaigns facilitates an enhanced role for single candidates in elections more generally speaking (Karvonen 2010).

In Switzerland, due to the militia character ${ }^{2}$ of the national parliament, members of parliament (MPs) maintain close ties to various interest groups and often are in leading positions at interest groups or companies. While some MPs hold such positions prior to being elected, interest groups also recruit politicians actively once they are elected into the leadership positions of their organizations (Eichenberger and Mach 2017; Gava et al. 2017).

Interest group ties may help candidates to be elected. The electoral performance of individual candidates is highly relevant to elections in Switzerland because of its open ballot proportional representation (PR) system. A candidate is elected if the party wins one or more seats and, at the same time, if the candidate wins more preference votes than the other candidates on the same list. As a consequence, candidate competition is sometimes more intense within the same party than between parties (Selb and Lutz 2014). The vote differences between candidates of the same party list are sometimes very small. Therefore, interest group support during electoral campaigns can make a difference regarding whether a candidate is elected or not.

We show that for individual candidates, interest group support plays a role in generating more votes, but this is not true for all interest group types or for all candidates to the same extent. Variations in influence exist across different interest group types and

\footnotetext{
2 The "militia system" refers to the fact that MPs occupy a major profession adjacent to their political mandate (for more details, see Wiesli 2003 or Pilotti 2017).
} 
parties. Mainly, support from a public interest group has a positive (although limited) impact overall on electoral success.

The paper is structured as follows. We first present our analytical framework and hypotheses. Then we present the data and methods used in this article. In the results section, we address the relationships between candidates and interest groups in elections and explore to what extent these relationships have an impact on electoral outcomes. We run a multi-level regression model with candidate preference votes as the dependent variable and leadership positions, endorsements and contributions by interest groups as independent variables.

\section{Interest Groups in Electoral Politics: Support and Electoral Success}

Interrelations between interest groups and parties are multifaceted with many mutual interests and benefits (Allern and Bale 2012). For interest groups, maintaining strong links to parties and politicians helps to influence relevant policies in the direction of the groups' interests. Influence seeking takes place through lobbying, either directly or through specialized lobbying companies, that targets the parliament or the administration. Through lobbying, interest groups feed their views and sometimes concrete proposals into the decision-making process, using a variety of instruments. The stronger the ties with MPs, the easier it is to lobby since lobbying relies, to a large extent, on access.

For political parties, it might also be beneficial to entertain close relationships with interest groups. They can receive different forms of support from interest groups (financial, expertise or logistical support) during their political activities, ranging from electoral campaigns to legislation drafting. In addition, party members occupying leading positions within interest groups allow parties to control interest groups' resources and, to some extent, their political strategies.

While political lobbying directed toward parliament, MPs and the administration is the subject of a vast number of studies on interest groups (see Baumgartner et al. 2009; Bigelow and Herrnson 2008; McKay 2018; Stratmann 2005; and Weiler and Brändli 2015 for reviews of literature on the subject), "lobbying activities" that occur at an earlier stage of electoral campaigns remain largely understudied in Europe. Establishing a relationship by supporting parties and candidates prior to their election can be seen as an extension of the lobbying activities conducted outside the parliamentary sphere. Incumbent candidates may receive support from interest groups in return for previous support of certain policies. Supporting non-incumbent candidates may, however, be particularly beneficial in the long run since an interest group takes a risk by "investing" in candidates who have not yet been elected. If a candidate then becomes elected, this means that a direct link to parliamentary decision-making is established.

Since we focus our analysis specifically on the impact of interest groups on candidate campaigns and electoral success, it is necessary to distinguish between existing connections between interest groups and parties at a general level (formal ties through overlapping memberships and holding leading positions; see Allern and Bale 2012) and the active support of interest groups during electoral campaigns through financial contributions or endorsements. In addition, electoral success is not simply defined as being elected, but refers to the number of preference votes candidates receive. This allows the intra-party competition on the same electoral list to be better conveyed (see Selb and Lutz 2014 and the Data and Methods section below). 
Linkages between specific interest groups and parties have been strong on an organizational and a personal level since an early stage of the Swiss democracy. As shown by Gruner (1977), many parties as well as interest groups historically emanated from the same social and political movements in Switzerland. Socialist and social democratic parties were formed out of the labor movement at the same time as trade unions. Agrarian interest groups like the Swiss Farmers Association as well as the centrist "BauernGewerbe- und Bürgerpartei" that later turned into the Swiss People's Party came out of the agrarian movement that started in the early $20^{\text {th }}$ century. New social movements from the left during the 1970s led to the formation of new left parties, such as the green parties, as well as large environmental organizations. In Switzerland, close ties connect MPs and political parties to interest groups because of the weakly professionalized parliament and the absence of public funding of political parties. Political parties are central in direct democratic campaigns, too; however, they largely rely on interest groups for financial support, expertise or campaigns during popular votes as well. Gruner (1977: chap. 10) has shown the strong connections between parties and various important interest groups (for a more recent analysis, see Ladner 2015). Close relations between interest groups and parties have always prevailed in Switzerland, such as between the Swiss Trade Union Federation (SGB/USS) and the Social Democratic Party (SP/PS) (Erne and Schief 2016), the main Swiss Farmers Association (SBV/USP) and the Swiss People's Party (SVP/UDC) or center-right MPs and business associations. This is also true for the Green Party and environmental associations. Many candidates and MPs therefore often hold leading positions at interest groups, and interest groups actively recruit national MPs or prominent politicians into leading positions. This is often done after an election, but filling seats with promising politicians prior to their potential election can establish a strong relationship in the long run.

Strong ties between some parties and interest groups affect interest groups' involvement in the pre-election phase. In some cases, non-party actors influence candidate selection or are allowed to occupy some places on a party list (see Rahat 2008). Traditionally, strong links between trade unions and social democratic parties have existed. In Switzerland, it was common that the lists even included the name of an interest group as in "SP und Gewerkschaften" and the trade unions had reserved seats. Having candidates on the lists that "represent" different, important parts of the electorate also works beyond such direct links. Liberal parties have close ties to business associations and are keen on having business leaders on their lists. Agrarian parties want to have ties to farmers and the organizations that represent them (for an early discussion of these points during previous electoral campaigns, see Gruner 1977: 169; Gruner and Siegenthaler 1964).

In the context of a weakly professionalized parliament, where politicians maintain close relationships with interest groups and there is a lack of public funding for parties during electoral campaigns, support from interest groups can have an important impact on electoral success. In addition, highlighting close relationships with interest groups is generally well accepted by the electorate, showing that candidates are active in civil society and not professional politicians detached from the population.

While interest groups provide political parties and MPs knowledge, produce policy briefs and, in some cases, even draft legislation, interest groups' support can also become important during electoral campaigns. This factor led us to develop hypotheses along two dimensions on the impact of interest group support on electoral success: The first dimension (hypotheses 1 to 3 ) is relative to the direct overall impact of different types of support on electoral success; the second dimension (hypotheses 4 and 5) focuses on the 
differentiation in the efficacy of support, according to interest group type (hypothesis 4) and according to party and interest group affinity (hypothesis 5). This differentiation has been made as a way to distinguish between potentially conflicting results. The first three hypotheses are related to the overall effect of interest groups' ties on electoral success, without distinguishing between interest group types and parties, thus ignoring the possible negative effect that ties with and support from certain interest group types could have on electoral success. However, hypotheses 4 and 5 attempt to correct this problem by focusing on specific interest group types and parties, highlighting the affinities between the two.

We can distinguish different forms of active support: The two main instruments are financial contributions and public endorsements. First, parties and candidates may benefit from interest groups' resources. Interest groups typically fund political parties and candidates or provide in-kind contributions in the form of logistical support. The U.S. literature provides a comprehensive analytical framework for the analysis, according to which contribution patterns can be categorized and systematized. However, this framework is only partially applicable to Switzerland because of the many institutional differences that exist between the two countries, notably with respect to campaign finance regulations, electoral rules (majoritarian vs. proportional electoral systems) and campaign traditions (for example, door-to-door canvassing almost does not exist in Switzerland). Nevertheless, general concepts about interest group strategies in campaigning can be applied to the Swiss context as well.

According to Austen-Smith (1987), contributions are provided for two non-mutually exclusive reasons. On the one hand, interest groups might follow an "electoral strategy," meaning that they want certain candidates - most importantly, their own members and leaders - to be elected. On the other hand, they might prefer an "access strategy," which means contributing to the campaigns of successful politicians to gain their sympathy and obtain policy goods later on (Grossman and Helpman 1996). When following an electoral strategy, interest groups might prefer to support their own members because they are the most likely to provide them with reliable policy rewards once elected. Evidence of this mechanism is present in many U.S. studies, showing that interest groups contribute substantially to longstanding allies. Inversely, when following an access strategy, campaign contributions depend on the probability of the election of a candidate and the contributions received by opponent candidates. However, generally speaking, donations mostly flow to incumbents during close races, while they tend to be much less important when the election is lopsided (Stratmann 2005).

The extent to which such contributions matter outside the U.S., however, is controversial. Studies from other different countries have shown that campaigning has only a marginal impact on electoral success (as shown by Farrell and Schmitt-Beck 2002 with reference to different country studies). When other candidate qualities, like political experience (based on factors unrelated to campaigning), are considered, financial contributions have a positive, although marginal, impact on candidates' electoral success notwithstanding their electoral status, as Stratmann (2005) notes in his literature review of several pre-existing studies.

So, how do interest group contributions increase candidates' electoral success? Financial contributions are important campaign resources (see Potters and Sloof 1996). They allow candidates to target voters and convince them to give a preference vote to a specific candidate and thus contribute to his or her electoral success (see Bühlmann et al. 2016; Lachat and Sciarini 2002). This is especially relevant in the Swiss context because campaigns are relatively expensive and competitive (Selb and Lutz 2014). Parties also do 
not receive public funding or funds from their party for their personal campaigns. In the Swiss context, where contributions are not disclosed, interest groups are free to provide candidates and parties campaign funds in any form and for any reason. Contributions to candidates, which also include private contributions, amounted to $1872 \mathrm{CHF}$ per candidate or over 7 Mio. CHF total in 2015, according to the candidates' self-declarations (Lutz 2016: 63).

Hypothesis 1: Contributions from interest groups have an overall positive effect on candidates' electoral success.

A second way for interest groups to support candidates is through public endorsements, which means candidates receive public support. While financial contributions are more typical of wealthy organizations, endorsements are rather typical of trade unions, environmental groups and sports groups, which have fewer funds per member (Bigelow and Herrnson 2008). Some interest groups have a large membership base with its own communication channels, like newsletters or magazines, which are used to communicate with its members. Many politically oriented interest groups use these communication channels to endorse specific candidates or parties before an election. Such endorsements can be highly valuable for a party or a candidate. In some cases, interest groups' endorsements depend on candidates' public support of specific policy positions. Some interest groups have started to conduct their own surveys prior to recent elections, in which they request that candidates position themselves around specific policies. They then endorse only those candidates who align with their policy positions. Alternatively, interest groups report the positions of all candidates, publicly shaming those who are not in line with their policy preferences.

Endorsements function as a psychological cue used by voters (Weber et al. 2012). Most voters have little information on individual candidates when the number of candidates in a constituency is large. Voters can use cues to reach somewhat "good" or "accurate" decisions, as if they had full information (Weber et al. 2012). It is difficult for most voters to judge candidates in terms of their political profiles, policy preferences or leadership qualities, not the least because such information is largely absent or can only be found by actively gathering information (e.g., through using voting aid applications, such as smartvote in Switzerland). Interest group endorsements provide information to voters regarding what the candidates stand for. If environmental or farmers' groups support a candidate, voters can assume that the candidate identifies with the goals of these organizations. In addition, endorsements by organizations that are well-known and respected by many voters can enhance a candidate's credibility. Endorsements function as "stamps of approval," mobilizing and motivating members and sympathizers of a given interest group to support certain parties and candidates (Bigelow and Herrnson 2008). Cues are, of course, not limited to interest groups. The cue effect on voting has been reported by other studies (Weber et al. 2012) that focus on a number of candidate features, such as appearance (Lutz 2010a), ballot position, (Lutz 2010b), gender (Schwindt-Bayer et al. 2010) and occupation (Mechtel 2014). Other information written on the ballot paper may provide additional cues to voters in the low-information ${ }^{3}$

\footnotetext{
3 "Low-information" elections are identified as elections with a high number of candidates and little media and campaign focus on individuals that, rather, focus on party competitions in which voters do not, in general, have the ability to fully and individually recognize most candidates. In these elections, voters tend to rely on informational cues provided by other sources. For more details, see Mechtel (2014).
} 
context of the Swiss federal elections as well, such as the place of residence or age of a candidate.

Hypothesis 2: Endorsements have an overall positive effect on candidates' electoral success.

Holding a leading position in an interest group can have an additional impact on electoral success. Occupying a leading position sends a signal to voters that a candidate plays an important role in this interest group and also that the candidate is engaged in some executive function, which many voters may view positively. Holding a leading position does not guarantee active support from an interest group; however, candidates often refer to their role in organizations in their campaign material (flyers and leaflets). Candidates with a leading position in an interest group are likely also already better known by the organization's members than ordinary members, and it is easier for them to communicate to potential voters outside their organization. Such signaling essentially functions as an endorsement by an interest group.

Hypothesis 3: Holding leading positions in interest groups has an overall positive effect on candidates' chances of electoral success.

If we treat public endorsements and holding leading positions as electoral cues that voters can use to cast a vote for certain candidates, then we should take into account that not all interest groups have a positive image with all voters. Voters may see some endorsements and leading positions positively, whereas some voters may view them negatively. For example, being in a trade union may serve as a positive cue for left-wing voters, while a right-wing voter sees this as negative. Therefore, trade-union membership is not useful for a right-wing candidate to increase electoral success or it might even have a negative impact.

Typically, we can expect that public interest groups with a broad and general focus tend to have a positive image among many voters, while specialized and narrow interests tend to divide voters. Being associated with such groups, then, may not bring the expected positive effect on electoral success and can even be risky (McDermott 2006). It is therefore also part of the electoral strategy of candidates to seek official endorsements in a selective manner from positively perceived interest groups. On the contrary, candidates might remain much more discrete about their leading positions or endorsements from some sectional and specialized interest groups where they perceive risks.

Hypothesis 4: Support from public interest groups has a more positive impact on electoral success than support from more specialized interest groups.

Finally, as a complement to hypothesis 4, we should also take into account the traditional link between certain interest groups and parties and candidates. We can expect that interest group support of a traditional ally and support from groups with similar policy preferences and interests as the candidate's political party will have a bigger impact on the candidate's electoral success. As illustrated by Gava et al. (2017: 86), MPs and parties maintain privileged relationships with some interest groups.

Occupying a leading position or being endorsed by a traditional ally provides an especially positive cue for a candidate during electoral campaigns. Therefore, we expect holding leading positions in trade unions or public interest groups to have a greater positive effect for center-left candidates. For right-wing parties, however, we expect a positive effect on electoral success to be gained through relationships with business associations. 
Hypothesis 5: Support (endorsements and leading positions) from trade unions and public interest groups increases the electoral success of left-wing candidates, while support from business associations, professional groups and firms increases the electoral success of right-wing candidates.

\section{Data and Methods}

Our analysis is based on data from the Swiss Comparative Candidate Survey (CCS), which was conducted in the framework of the Swiss Electoral Studies (Selects) after the 2015 national elections. A total of 1754 out of 3802 candidates $(46 \%)$ for the National Council completed the questionnaire. The response rate varied between parties. More candidates from left-wing parties responded than candidates from right-wing parties. Fifty-three percent of the Social Democratic Party (SP/PS) ${ }^{4}$ and the Green Party (GPS/PES) candidates participated in the surveys. For the Green Liberal Party (GLP/PVL) and the Christian Democratic Party (CVP/PDC), the response rate was about 50\%; for the Liberal Party (FDP/PLR) and the Conservative Democratic Party (BDP/PBD), the response rate was around $45 \%$ and for the Swiss People's Party (SVP/UDC), the response rate was just below $40 \%$. We did not consider these differences to be problematic because we apply multi-level models later on, which mainly look at the within-party list differences of candidates' performances at election time. In the following analysis, we also only consider the respondents from the main seven parties mentioned above, which leaves us with 1375 candidates in the data set. Combined, the seven parties hold 193 out of 200 seats in the National Council.

This comprehensive survey questionnaire, sent to all candidates, asked questions about candidates' political backgrounds, their electoral campaigns and their political preferences and attitudes toward democracy.

\subsection{Measuring Interest Group Relationships with Candidates}

In addition to the standard CCS questionnaire, candidates were asked to specify their relationships with interest groups in detail. Interest groups are defined as organizations of individuals, groups or firms that seek to influence the policy process and political outcomes and that do not seek public office. In addition, we consider individual firms that have been mentioned by some candidates.

Candidates were first asked to list all organizations and associations with which they have a relationship (up to 15 organizations). In a follow-up question, they were asked to specify the nature of the relationship with each organization: It could be formal ties (such as simple memberships, being employed by the organization or being a board member) or ad-hoc support during the electoral campaign (financial contributions or public endorsements). To measure the "leading position" effect, the categories "employed by the organization" and "board member" were regrouped into a new category labeled "leading position," as opposed to "simple member." In a second follow-up question, candidates were asked what contribution the organization made to the campaign, and the categories provided were "funding of ads and flyers," "endorsements," "logistical support" and

\footnotetext{
${ }^{4}$ For party abbreviations, we will use the official German and French abbreviations: Swiss People's Party (SVP/ UDC), Liberal Party (FDP/PLR), Christian Democratic Party (CVP/PDC), Conservative Democratic Party (BDP/PBD), Green Liberal Party (GLP/PVL), Green Party (GPS/PES) and Social Democratic Party (SP/PS).
} 
"financial support." To simplify the analysis, we combined funding ads and flyers and financial support into one variable ("contributions") and kept endorsements as such ("endorsements"), and because of the low number of cases, we dropped "logistical support" from the analysis. ${ }^{5}$

Not every candidate reported interest group relationships. We could not distinguish if this is because no relationships exist or because a candidate did not want to respond to the question. We therefore only included candidates who indicated at least one interest group relationship. This reduced the number of candidates included in the analysis further to 1070 .

Great effort was required to code the many different organizations mentioned by the candidates into different categories. The number of organizations cited was very large in the data set. Overall, we classified 4865 relationships between candidates and organizations for this analysis. Several candidates classified different party offices under "interest groups." Since these activities are part of their party activities, we ignored them.

Figure 1 shows general characteristics of the formal ties (memberships and leading positions) of party candidates and interest groups. On average, candidates from the main seven parties reported 4.5 linkages to interest groups. However, there is substantial-and, to some extent, counter-intuitive-variation. Candidates from left parties have the highest average number of interest group linkages: 6.2 for Green Party (GPS/PES) and 5.3 for Social Democratic Party (SP/PS) candidates on average. Candidates from center-right parties have fewer interest group linkages: 3.3 for Conservative Democratic Party (BDP/ PBD) candidates, 3.4 for candidates from the Liberal Party (FDP/PLR) and 3.6 for those from the Swiss People's Party (SVP/UDC). Christian Democratic Party (CVP/PDC) candidates reported 4.1 interest group linkages.

At the same time, and as shown in Figure 1, most of the ties reported by the candidates of these two parties are simple memberships. When we focus on leading positions, the differences between parties are not very large and candidates hold, on average, one leading position. Candidates from larger and centrist parties (FDP/PLR, $\mathrm{CVP} / \mathrm{PDC}, \mathrm{SP} / \mathrm{PS}$ ) tend to hold slightly more leading positions than candidates from smaller parties or the right-wing SVP/UDC. Finally, we see that center-right candidates have fewer ties to interest groups, but they more often hold leading positions in these organizations.

The interest groups were classified based on the Interarena coding scheme. ${ }^{6}$ This scheme categorizes interest groups according to their membership and aims. Our slightly adapted coding scheme distinguishes seven interest group categories: ${ }^{7}$

(1) Trade unions

(2) Business interest associations

(3) Professional groups (such as doctors' associations [FMH], teachers [LCH], firefighters and army officers ["Offiziersgesellschaft"])

\footnotetext{
${ }^{5}$ In the absence of legislation that requests public disclosure of campaign funds in Switzerland, information about the monetary value of interest group contributions could not be gathered. We only asked about the overall campaign funds, not for the amount given by every interest group in the CCS questionnaire. This limits the quality of the data because we could only count the number of reported contributions but not the amount.

${ }^{6}$ For more details, see http://interarena.dk and Gava et al. (2017).

${ }^{7} \mathrm{We}$ also coded support from institutional and religious groups. However, they were not taken into account because of the small number of organizations mentioned in these groups.
} 
Figure 1: Average Number of Formal Ties with Interest Groups per Party

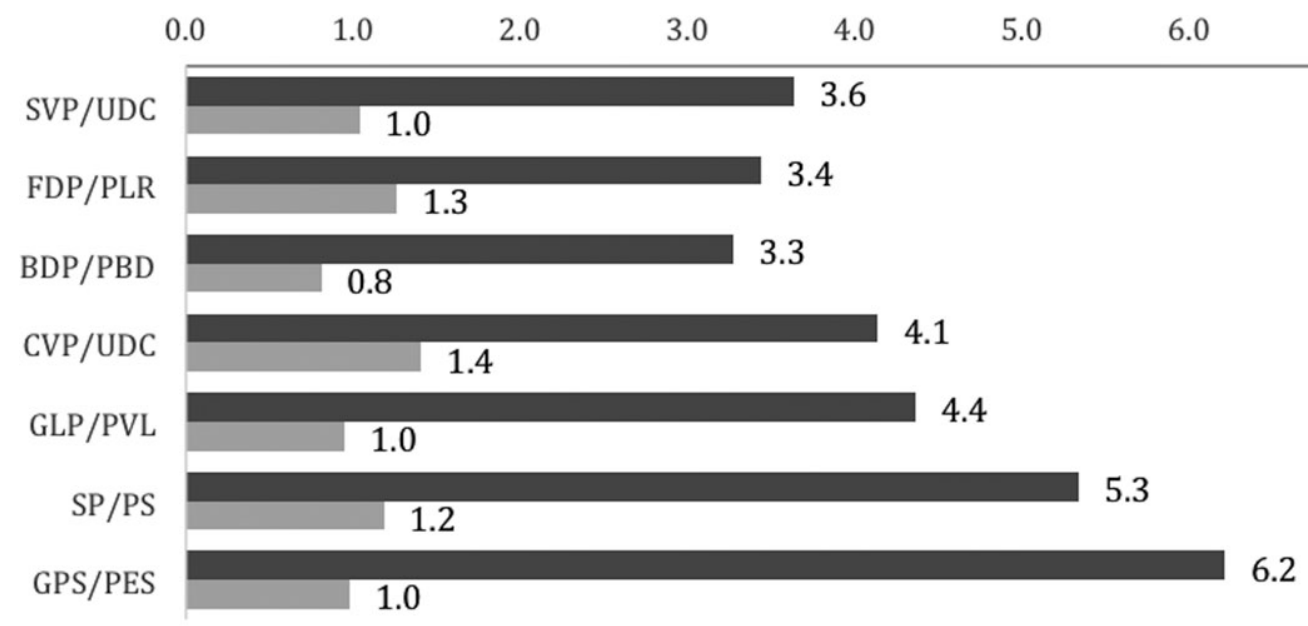

Number of ties Number of leading positions

(4) Identity groups: This rather heterogeneous group includes sectional organizations, such as older adult organizations, women's associations (Frauenzentrale), LGBTQ + groups (Pink Cross) and students and tenants (SMV/AsLoca)

(5) Sport/leisure groups and sport club memberships

(6) Public interest groups: This group type is also rather heterogeneous, but it is identified as being non-sectional (i.e., defending a public cause). Some examples are environmental groups, humanitarian groups and political and/or ideological groups and NGOs, such as the nationalist AUNS/ASIN, the pro-European NEBS/NOMES or the anti-military GSoA/GSSA.

(7) Firms: This category contains private companies, public firms and cooperatives.

The distribution of interest groups is not even. The candidates mentioned 204 formal ties to trade unions, 410 to business interest associations, 418 to professional groups, 509 to identity groups, 757 to sport/leisure organizations, 2274 to public interest groups and 298 to firms.

If we examine the types of interest groups and the specific nature of their ties to particular parties, a more precise and disaggregated picture of interest group and party relationships emerges.

Figure 2 shows the share of candidates reporting at least one tie to an organization from the different category types. The distribution shows some expected patterns. ${ }^{8}$ We can see the historical links between specific parties and groups: Trade unions are predominantly mentioned by SP/PS candidates $(48 \%$ of them mentioned at least one trade union), only marginally mentioned by GPS/PES (17\%) and never mentioned by right-wing parties (SVP/UDC and FDP/PLR). Conversely, associations with business interests are

\footnotetext{
${ }^{8}$ The distribution of ties is relatively similar to MPs' ties, as reported in the official registry on MPs' interests (see Gava et al. 2017). The proportion of public interest groups mentioned in the survey is even higher than among MPs.
} 
most frequently mentioned by candidates from central and right-wing parties and less frequently by candidates from left-wing parties. Compared to these two categories, other interest group types are reported more evenly across parties. Professional groups and sport/leisure groups are slightly more represented among center-right parties and identity groups and public interest groups are slightly more represented among left-wing parties. Finally, firms are mentioned by candidates of all parties, but at a relatively low level. This is mainly due to the large share of public companies and cooperatives represented in the data. Most firms mentioned by left-wing candidates belong to these two sub-categories.

Looking at the nature of the ad-hoc support interest groups provided during the electoral campaign (including leading positions), we can see quite some variation (see Table 1). Twenty-five percent of the candidates hold a leading position in the organization they have mentioned, $16 \%$ of the candidates were endorsed by the organization and only $7 \%$ received a contribution. There are some important differences between parties. For the two traditional center-right parties (FDP/PLR and CVP/PDC), one-third of the candidates hold a leading position in the interest group they mentioned. This total is $29 \%$ for the right-wing SVP/UDC. For smaller parties and left-leaning parties, this figure is lower. SP/ PS candidates and GLP/PVL candidates occupy leading positions in only $22 \%$ of the interest groups they mentioned, and GPS/PES candidates only hold such positions in 16\% of cases. This confirms the picture described above that Green and Social Democratic Party candidates have many relationships, but this does not mean that they have a strong position within interest groups.

The distribution of endorsements is less nuanced between parties. Overall, $16 \%$ of the organizations a candidate is linked to also endorse the candidate. Thus, the majority of organizations does not endorse a candidate. The percentage of organizations that endorse a candidate is slightly higher for candidates from the SVP/UDC and the BDP/PBD and slightly lower for candidates from the Green Liberal Party (GLP/PVL). Contributions are relatively rare. Only $3 \%$ of the organizations contribute financial support to a candidate's campaigns, with the highest number reported for the Swiss People's Party (SVP/UDC) candidates.

Differences also exist between different types of interest groups. Candidates who report links to business associations and firms more frequently report leading positions in such organizations. In the case of firms, roughly half of the candidates reporting relationships with firms also reported leading positions. For all other interest group types, this share is around 20 to $25 \%$. Enormous variation exists regarding endorsements. Trade unions endorse $43 \%$ of the candidates they have relationships with. For business associations, one of four candidates is endorsed. Sports/leisure organizations have a much lower frequency of endorsing candidates; only $11 \%$ of the candidates receive an endorsement from such groups. The lowest share of endorsements comes from firms. Firms only endorse $4 \%$ of the candidates who have a link to a firm. The two categories with the lowest shares are, not surprisingly, those organizations with the lowest level of political involvement.

\subsection{Measuring Electoral Success and Control Variables}

In this paper, we explore how interest group relationships impact electoral success, which raises the question of how to measure electoral success. In a strict sense, electoral success refers to whether somebody is elected. However, this definition leaves very limited analytical leverage to study the influence of different factors since incumbency plays a decisive role and only a small minority of non-incumbent candidates are elected. 
Figure 2: Interest Group Ties for Different Groups by Party

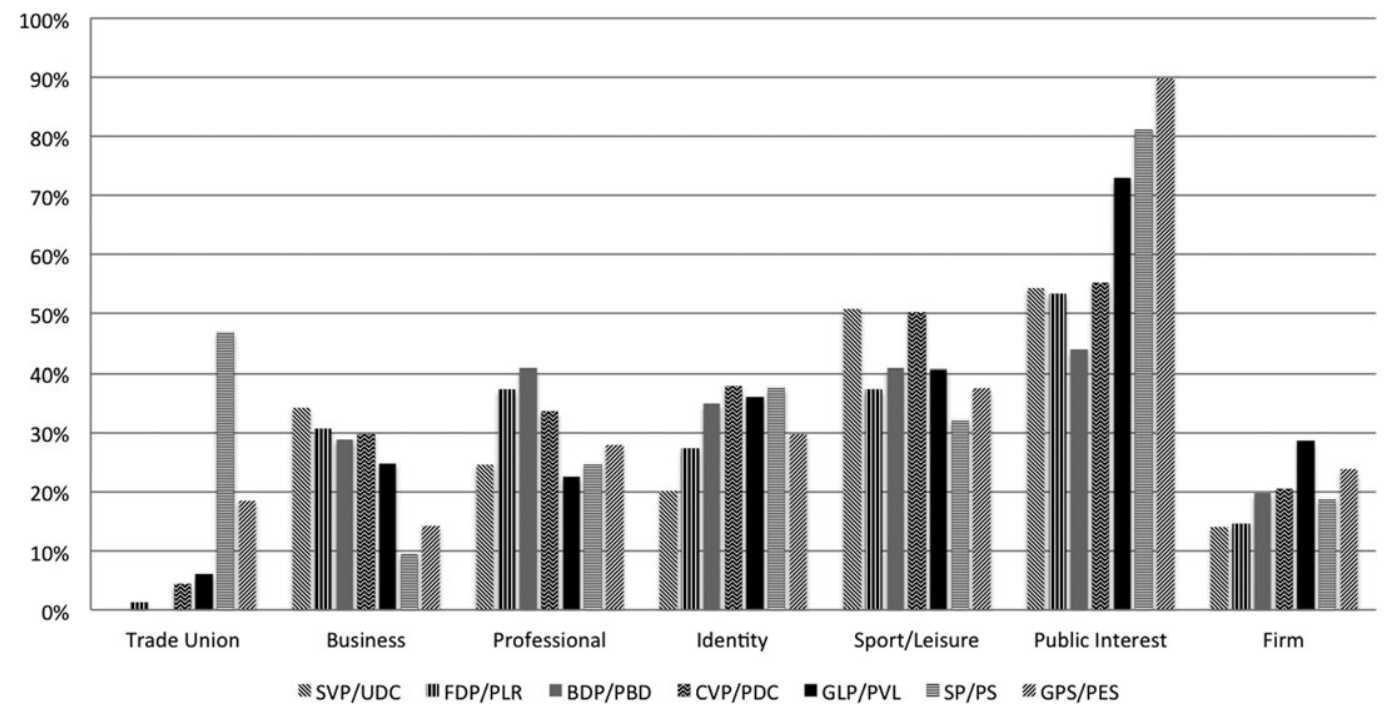

Table 1: Nature of Support Provided by Interest Groups and Received by Candidates (by Party and Interest Group Type)

\section{BY PARTY}

\begin{tabular}{lcccc} 
& \% Leading positions & \% Endorsements & \% Contributions & N ties \\
\hline SVP/UDC & 29 & 19 & 6 & 462 \\
FDP/PLR & 36 & 16 & 3 & 540 \\
BDP/PBD & 24 & 21 & 4 & 244 \\
CVP/PDC & 34 & 15 & 1 & 703 \\
GLP/PVL & 22 & 12 & 3 & 610 \\
SP/PS & 22 & 17 & 3 & 1174 \\
GPS/PES & 16 & 16 & 3 & 1137 \\
\hline
\end{tabular}

BY INTEREST GROUP TYPE

\begin{tabular}{lcccr}
\hline & \% Leading positions & \% Endorsements & \% Contributions & N ties \\
\hline Trade unions & 22 & 43 & 4 & 204 \\
Business & 28 & 25 & 6 & 410 \\
Professional & 19 & 19 & 2 & 418 \\
Identity & 23 & 21 & 2 & 509 \\
Sport/Leisure & 26 & 11 & 1 & 757 \\
Public interest & 22 & 14 & 3 & 298 \\
Firms & 47 & 4 & 3 & 298 \\
\hline
\end{tabular}

Incumbent candidates generally have much higher chances of being re-elected than their non-incumbent peers (for more details, see Carson et al. 2007). This creates a problem of endogeneity between incumbency and electoral success. Incumbency is positively correlated with the quantity and intensity of ties. Many interest group ties are established once an 
MP is in office (Eichenberger and Mach 2017), so for the incumbents, it is impossible to distinguish to what extent interest group ties explain electoral success or if the relationship is reversed and electoral success explains interest group ties. Because of these issues, we dropped incumbent candidates from the analysis and our analysis includes only nonincumbent candidates. It was also not possible to compare incumbent with non-incumbent candidates because the number of incumbents in the data set is too small (only 56 respondents).

We measure electoral success according to the number of preference votes the candidates received. In Switzerland, voters can cast different types of preference votes for candidates (Lutz 2010b; Selb and Lutz 2014). On the pre-printed ballots, candidates are listed in an order determined by the parties. Voters can either vote using a pre-printed ballot without any changes or they can also modify the pre-printed list by doubling names (cumulation), adding candidate names from other lists (panachage) or deleting names. Alternatively, voters can take an empty ballot and fill in candidates of any party and in any order. Cumulative and panachage preference votes follow a slightly different logic. Cumulative preference votes come from own-party voters who single out candidates within the party they voted for. Panachage preference votes come from voters who have used a ballot paper from another party.

Voters can vote for as many candidates as their canton of residence has seats. This means that, in large cantons, voters can give up to 34 preference votes, and in small cantons, such as Uri, they only have one preference vote for a single candidate. Many voters use pre-printed ballots that they only modify with a few names. Candidates from larger parties in larger cantons therefore receive many more votes than candidates from smaller parties and smaller cantons. If we were to simply use the number of preference votes, we would rather measure cantonal and party size than electoral success. Preference votes therefore need to be weighted according to the total number of ballots cast for each party (see Selb and Lutz 2014 for a more detailed discussion of this measure). This standardized measure facilitates a comparison of the performance of each candidate to the performance of their fellow candidates on the same party list, as well as to candidates from different party lists. So, if this indicator has a value of 1 , this means that a candidate receives, on average, one preference vote per party voter. Because the distribution is still skewed toward lower values after this standardization, we transposed the dependent variable into its logarithm.

Switzerland has more than $90 \%$ postal voting, which means that the large majority of voters fill out their ballots at home. Many parties and candidates send or distribute their campaign material to the households and these flyers list the candidates' interest group associations and, typically, also the different positions they hold in public or party offices as well as in different interest groups. This means that voters actually have this kind of information at hand when they fill out their ballots.

Additional factors (which are beyond a candidate's control) may influence the number of preference votes they receive, such as gender (Engeli and Lutz 2014; Schwindt-Bayer et al. 2010), age or previous political experience. Those factors will not be central in our analysis but need to be included as control variables. The control variables are related to candidates' individual ability to receive votes, regardless of their interest group ties and support received. Control variables are divided into two main categories: personal variables that vary for each individual and that are strictly related to their non-political activity and identity (including age and gender) and political variables that are directly tied to political activities and political experience (seniority in the party and occupied party 
offices at the local or national level). We assume that the longer a candidate has been in the party, the more he or she will be known and attract preference voters. We assume that candidates who have occupied party offices at the local or national level might be better embedded among party voters, but also among voters at large, and therefore are also more well-known than their counterparts who did not occupy such party offices.

\section{Results ${ }^{9}$}

We now look at the impact of interest groups on electoral success. As explained above, the dependent variable in the models is the number of preference votes for each candidate, standardized by accounting for variation in the party and electoral district size. We further distinguish between preference votes from own-party lists and panachage preference votes from other lists. Our main interest is to test the impact of candidates' interest group ties on electoral success.

As discussed above, we have to take into account that candidate competition is, in most cases, considerably more relevant within parties than between parties (see Selb and Lutz 2014). Elections depend on whether candidates do better than their fellow candidates on the same list, while the score of candidates from other lists is irrelevant. This is true for all factors that potentially explain electoral success. As candidates are nested within lists, and as we are mainly interested in how candidates perform compared to other candidates on the same list, we applied multi-level models with two levels. Individual candidates are the lower level unit and the lists are the higher-level unit. We first ran models including all candidates from all major parties. In the first model, we did not distinguish between different forms of organizations, but simply counted the number of endorsements and of leading positions, as well as the number of contributions per candidate for all interest groups. We also controlled for gender, age, years of membership in the party and the party offices held at the local and national level.

Table 2 shows the results from this analysis. Holding many leading positions has a significantly positive impact on the number of preference votes: The more leading positions candidates occupy, the more preference votes they receive from their own party lists and from other party lists (panachage votes). The same is true for the number of endorsements. Candidates with many endorsements receive more panachage votes and votes from their own party lists. So, being visible in public in the short and in the long run has a positive effect on the number of votes a candidate receives. The effects on votes for the candidate's own party are stronger than the effects on panachage votes, so being endorsed and holding leading positions matter slightly more for own-party voters than for voters from other parties.

Contributions from interest groups do not have a significant impact, which is not surprising given that interest groups rarely contribute directly to candidates' campaigns. Based on these results, we can confirm hypotheses 2 and 3, but not hypothesis 1 .

Furthermore, the confirmation of hypotheses 2 and 3 provides exploratory evidence for the existence of the electoral effect of relationships with interest groups. In lowinformation elections, such as in Switzerland, voters do not have the time to inform themselves about every candidate. Occupying a leading position or receiving an endorsement from an organization thus seem to make candidates recognizable when voters

\footnotetext{
${ }^{9}$ More detailed data and results can be consulted in the online appendix at the Swiss Political Science Review's official website.
} 
Table 2: Multilevel Models Explaining Interest Group Support and Electoral Success

\begin{tabular}{|c|c|c|c|c|}
\hline \multirow[b]{2}{*}{ Interest group support } & \multicolumn{2}{|c|}{$\begin{array}{c}\text { Model 1: Votes from own } \\
\text { lists }\end{array}$} & \multicolumn{2}{|c|}{ Model 2: Panachage votes } \\
\hline & Coef. & SE & Coef. & $\mathrm{SE}$ \\
\hline Number of endorsements & 0.029 & $0.009 * * *$ & 0.048 & $0.020 * *$ \\
\hline Number of contributions & -0.019 & 0.018 & -0.018 & 0.038 \\
\hline Number of leading positions & 0.022 & $0.007 * * *$ & 0.034 & $0.014 * *$ \\
\hline Gender (female) & 0.068 & $0.022 * * *$ & 0.173 & $0.047 * * *$ \\
\hline Age & -0.004 & $0.001 * * *$ & -0.009 & $0.003 * * *$ \\
\hline Year in party & 0.009 & $0.002 * * *$ & 0.013 & $0.003 * * *$ \\
\hline Holding local party office & -0.001 & 0.025 & -0.019 & 0.053 \\
\hline Holding national party office & 0.100 & $0.032 * * *$ & 0.233 & $0.067 * * *$ \\
\hline Constant & -0.544 & $0.057 * * *$ & -0.209 & $0.117 *$ \\
\hline Random effects (s.d.) & 0.020 & & 0.036 & \\
\hline Residuals (s.d) & 0.008 & & 0.016 & \\
\hline $\mathrm{N}$ (candidates) & 1011 & & 1011 & \\
\hline $\mathrm{N}$ (lists) & 278 & & 278 & \\
\hline
\end{tabular}

$* \mathrm{p} \leq .05 * * \mathrm{p} \leq .01 * * * \mathrm{p} \leq .001$

fill out their ballots and provide voters electoral cues that they can use to identify outstanding candidates within a list.

The rejection of hypothesis 1 , however, could also be related to data limitations. We have only a few reported contributions and we don't have the amount that interest groups gave to candidates because this is considered sensitive information candidates don't have to reveal. The limited information about this dimension may limit the measurability of any effect. Better data, measuring the total amount of financial donations, is needed to truly test hypothesis 1 .

Looking at the control variables, we can also see that women receive, on average, more preference votes than men for votes from their own lists and in the form of panachage votes. This indicates that the electoral disadvantage, which women faced for a long time in Switzerland, has been reversed: Women currently receive more preference votes. So, the underrepresentation of women in parliament is not rooted in punishment by voters, but in their overall underrepresentation among candidates. Age is negatively related to preference votes: Younger candidates tend to obtain more votes when controlling for all other variables. Being in the party for more years - on average, candidates have been in the party for 10 years - also has a positive impact on preference votes. The same is true for holding a national party office $(12 \%$ of the candidates hold a national party office), but there is no measurable impact from holding local party offices. This could be related to the fact that $66 \%$ of the candidates hold a local party office, which means that the candidates are not very different from each other with respect to this criterion.

To test hypothesis 4, we now look at the separate effects for types of groups that either endorsed a candidate or in which candidates occupied leading positions. We did not include contributions because no overall effect could be detected, and we also did not expect the effects of contributions from specific groups to make a difference. For each group type, we included the number of endorsements and leading positions. 
The results reveal that public interest groups are the only group type whose support had an overall positive effect on electoral success, as illustrated in Table 3. Public interest group endorsements have a positive impact on the number of preference votes from both own-party lists and other-party lists (panachage votes), while the same does not apply for any other interest group type. This is consistent with our hypothesis 4, which states that public interest appeals to voters at large because they often have non-partisan demands (cf. McDermott 2006; Poguntke 2006). Public interest groups are usually also open to anyone who shares the group's mission. Other interest group types usually appeal to specific segments of the society only, which leads only selected voters to be concerned about their mission.

Holding a leading position in a public interest group has a positive effect only on preference votes from own-party lists but not on panachage votes. The reason for this may be that holding leading positions is mainly noticeable for own-party voters because of the visibility of these positions on the leaflets and flyers distributed by the parties. Endorsements, on the other hand, are rather visible through the communications from interest groups and therefore influence both panachage votes and votes from own-party lists, allowing candidates to stand out relative to other members of the same party to all voters who might support the causes of given interest groups, but not a particular party. As reported below, this effect is also seen in more detail when comparing the effects for candidates in individual parties.

We now want to examine the impact of different types of interest groups to test our hypothesis 5, which suggests that the impact of different types of interest group varies between parties. Therefore, we tested a series of models for candidates from each party. This substantially reduced the number of cases in each model; however, this is only a problem insofar as effects need to be rather large to be significant. In the following models, we only included endorsements and holding leading positions as variables for the different interest groups. Because candidates often only have one link to a specific interest group, we did not count the number of endorsements or leading positions for each interest group type, but created a set of dummy variables, with each indicating if a candidate has been endorsed or is in a leading position in each of the different interest group types.

Table 4 shows the relationship for candidates from the Social Democratic Party (SP/ PS) and the Green Party (GPS/PES) both separately and with endorsements and leading positions in all interest group types. Starting with support from trade unions, we can see that trade union leadership has no positive effect on votes from within-party lists for social-democratic candidates. That we cannot find an effect from leadership could be related to the traditional ties between social democrats and trade unions and the fact that membership in trade unions is a trait shared by a relatively large percentage of center-left candidates: $30 \%$ of social-democratic candidates hold leading positions in trade unions.

Thus, rather active forms of support, such as endorsements, have a more positive effect on the number of preference votes derived for Social Democratic Party (SP/PS) candidates. Candidates who have been actively supported by a trade union stand out compared to other candidates. Being endorsed by a trade union thus has a positive effect for social democrats for voters from their own party.

For Green Party (GPS/PES) candidates, leading positions in trade unions instead have a strong positive effect on panachage votes, but not on votes from their own lists. A possible explanation for this discrepancy is that for Green Party candidates, holding a central position in a trade union attracts extra preference votes from other left-party 
Table 3: Multilevel Model Explaining Interest Group Support and Electoral Success, Separating Effects by Type of Interest Group

\begin{tabular}{|c|c|c|c|c|}
\hline \multirow[b]{2}{*}{ Interest group support } & \multicolumn{2}{|c|}{$\begin{array}{c}\text { Model 1: Votes from } \\
\text { own lists }\end{array}$} & \multicolumn{2}{|c|}{$\begin{array}{l}\text { Model 2: Panachage } \\
\text { votes }\end{array}$} \\
\hline & Coef. & $\mathrm{SE}$ & Coef. & SE \\
\hline \multicolumn{5}{|l|}{ Leading positions } \\
\hline Trade Union & 0.05 & 0.06 & 0.00 & 0.12 \\
\hline Business & 0.04 & 0.03 & 0.09 & 0.07 \\
\hline Professional & 0.01 & 0.04 & 0.12 & 0.08 \\
\hline Identity & 0.00 & 0.03 & -0.01 & 0.07 \\
\hline Sport/Leisure & 0.03 & 0.02 & 0.06 & 0.05 \\
\hline Public Interest & 0.04 & $0.02 * *$ & 0.04 & 0.03 \\
\hline Firm & 0.03 & 0.02 & 0.12 & 0.05 \\
\hline \multicolumn{5}{|l|}{ Endorsements } \\
\hline Trade Union & 0.04 & 0.04 & -0.03 & 0.08 \\
\hline Business & 0.01 & 0.03 & 0.04 & 0.07 \\
\hline Professional & 0.05 & 0.04 & 0.04 & 0.08 \\
\hline Identity & 0.03 & 0.03 & 0.09 & 0.08 \\
\hline Sport/Leisure & 0.01 & 0.03 & -0.04 & 0.06 \\
\hline Public Interest & 0.03 & $0.02 * *$ & 0.10 & $0.04 * * *$ \\
\hline Firm & 0.16 & 0.13 & 0.33 & 0.28 \\
\hline Gender (female) & 0.06 & $0.02 * * *$ & 0.17 & $0.05^{* * *}$ \\
\hline Age & -0.01 & $0.00 * * *$ & -0.02 & $0.00^{* * *}$ \\
\hline Year in party & 0.01 & $0.00 * * *$ & 0.01 & $0.00^{* * *}$ \\
\hline Holding local party office & 0.00 & 0.03 & -0.05 & 0.05 \\
\hline Holding national party office & 0.09 & $0.03 * * *$ & 0.24 & $0.07 * * *$ \\
\hline Constant & -0.50 & $0.04 * * *$ & -0.40 & $0.09^{* * *}$ \\
\hline Random effects (s.d.) & 0.33 & 0.02 & 1.08 & 0.05 \\
\hline Residuals (s.d) & 0.29 & 0.01 & 0.62 & 0.02 \\
\hline $\mathrm{N}$ (candiates) & 1011 & & 1011 & \\
\hline $\mathrm{N}$ (lists) & 278 & & 278 & \\
\hline
\end{tabular}

$* \mathrm{p} \leq .05 * * \mathrm{p} \leq .01 * * * \mathrm{p} \leq .001$

voters, mainly voters from the Social Democratic Party. Occupying a leading position in a trade union allows Green Party candidates to stand out compared to other Green Party candidates.

Green Party candidates who are endorsed by identity groups receive more votes from their own lists as well as more panachage votes, showing that the traditionally strong relationship between supporters of identity-based new social movements and the Green Party has an effect for this party's candidates. Nevertheless, being endorsed by a trade union seems to have a negative effect on panachage votes, which is somewhat surprising and cannot fully be explained here.

Some other groups show significant effects. For candidates from the Social Democratic Party (SP/PS), we find a positive effect for endorsements from sport/leisure groups on votes from their own party and on panachage votes. We also find a clear positive effect for leading positions in identity groups (from panachage and their own-party lists) for Green Party candidates. Overall, we can confirm, to some extent, hypothesis 4 for leftparty candidates. 
Table 4: Left Parties and Support From Specific Interest Group Types

\begin{tabular}{|c|c|c|c|c|c|c|c|c|}
\hline \multirow[b]{3}{*}{ Interest group support } & \multicolumn{4}{|c|}{ Social Democratic Party (SP/PS) } & \multicolumn{4}{|c|}{ Green Party (GPS/PES) } \\
\hline & \multicolumn{2}{|c|}{$\begin{array}{l}\text { Model 1: } \\
\text { Votes from } \\
\text { own lists }\end{array}$} & \multicolumn{2}{|c|}{$\begin{array}{l}\text { Model 2: } \\
\text { Panachage } \\
\text { votes }\end{array}$} & \multicolumn{2}{|c|}{$\begin{array}{l}\text { Model 1: } \\
\text { Votes from } \\
\text { own lists }\end{array}$} & \multicolumn{2}{|c|}{$\begin{array}{l}\text { Model 2: } \\
\text { Panachage } \\
\text { votes }\end{array}$} \\
\hline & Coef. & $\mathrm{SE}$ & Coef. & SE & Coef. & SE & Coef. & SE \\
\hline \multicolumn{9}{|l|}{ Leading positions } \\
\hline Trade Union & 0.08 & 0.07 & -0.05 & 0.14 & 0.21 & 0.15 & 0.87 & $0.31 * * *$ \\
\hline Business & (omi & itted) & (omi & (tted) & 0.26 & 0.17 & 0.22 & 0.34 \\
\hline Professional & 0.06 & 0.05 & 0.17 & $0.10^{*}$ & 0.22 & 0.16 & 0.66 & $0.32 * *$ \\
\hline Identity & -0.01 & $0.00 *$ & -0.01 & $0.01 * * *$ & -0.05 & 0.10 & -0.35 & 0.22 \\
\hline Sport/Leisure & 0.01 & $0.00 * *$ & 0.02 & $0.01 * * *$ & 0.04 & 0.08 & 0.36 & $0.15^{* *}$ \\
\hline Public Interest & 0.04 & 0.06 & 0.02 & 0.12 & 0.14 & $0.05^{* *}$ & -0.06 & 0.11 \\
\hline Firm & 0.09 & 0.07 & 0.18 & 0.14 & -0.17 & 0.11 & -0.05 & 0.23 \\
\hline \multicolumn{9}{|l|}{ Endorsements } \\
\hline Trade Union & 0.12 & $0.05 * *$ & 0.07 & 0.11 & -0.12 & 0.09 & -0.39 & $0.19 * *$ \\
\hline Business & 0.08 & 0.15 & 0.46 & 0.32 & -0.22 & 0.26 & -0.19 & 0.51 \\
\hline Professional & 0.14 & 0.09 & 0.11 & 0.18 & 0.11 & 0.12 & 0.28 & 0.25 \\
\hline Identity & 0.07 & 0.08 & -0.01 & 0.16 & 0.24 & $0.09 * *$ & 0.76 & $0.19 * * *$ \\
\hline Sport/Leisure & -0.14 & 0.12 & -0.20 & 0.26 & 0.06 & 0.15 & 0.37 & 0.31 \\
\hline Public Interest & 0.00 & 0.05 & 0.17 & $0.10^{*}$ & -0.07 & 0.06 & -0.13 & 0.13 \\
\hline Firm & 0.23 & 0.28 & 0.78 & 0.57 & 0.42 & 0.38 & 0.25 & 0.96 \\
\hline Gender (female) & 0.06 & 0.05 & 0.17 & $0.10 *$ & 0.05 & 0.05 & -0.03 & 0.10 \\
\hline Age & -0.01 & $0.00 *$ & -0.01 & $0.01 * * *$ & 0.00 & $0.00 *$ & -0.02 & $0.01 * * *$ \\
\hline Year in party & 0.01 & $0.00 * *$ & 0.02 & $0.01 * * *$ & 0.01 & $0.00 * * *$ & 0.02 & $0.01^{* *}$ \\
\hline Holding local party office & 0.04 & 0.06 & 0.02 & 0.12 & -0.07 & 0.06 & -0.11 & 0.13 \\
\hline Holding national party office & 0.09 & 0.07 & 0.18 & 0.14 & 0.14 & $0.07 * *$ & 0.19 & 0.14 \\
\hline Constant & -0.60 & $0.08 * * *$ & -0.67 & $0.21 * * *$ & -0.54 & $0.08 * * *$ & 0.10 & 0.20 \\
\hline Random effects (s.d.) & 0.35 & 0.05 & 1.13 & 0.12 & 0.23 & 0.04 & 0.75 & 0.10 \\
\hline Residuals (s.d) & 0.25 & 0.02 & 0.50 & 0.03 & 0.29 & 0.02 & 0.56 & 0.50 \\
\hline $\mathrm{N}$ (candiates) & 199 & & 199 & & 175 & & 175 & \\
\hline $\mathrm{N}$ (lists) & 55 & & 55 & & 39 & & 39 & \\
\hline
\end{tabular}

$* \mathrm{p} \leq .05 * * \mathrm{p} \leq .01 * * * \mathrm{p} \leq .001$

Looking at the control variables, a surprising feature is that women in left parties do not receive significantly more votes than men. Years in party office and age, however, have the same effect as in the models presented in Table 2.

We now look at endorsements and leading positions for the two main right-wing parties, the Swiss People's Party (SVP/UDC) and the Liberal Party (FDP/PLR), as shown in Table 5. For both parties, we find a very limited impact of leading positions and endorsements from any type of interest group. For SVP/UDC candidates, leading positions in sports clubs and endorsements from professional organizations seem to have a minor positive effect on preference votes; however, all the other variables do not have any significant influence. For FDP/PLR candidates, holding leading positions in firms has a positive effect on panachage votes. Candidates who occupy leading positions at such organizations are entrepreneurs or managers (who occupy leading positions in private firms) or professionals (who project their collective interests in professional organizations), thus allowing us to suggest that profession and entrepreneurship (or rather its perception) 
Table 5: Right-Wing Parties and Support From Specific Interest Groups

\begin{tabular}{|c|c|c|c|c|c|c|c|c|}
\hline \multirow[b]{3}{*}{ Interest group support } & \multicolumn{4}{|c|}{ Swiss People's Party (SVP/UDC) } & \multicolumn{4}{|c|}{ Liberal Party (FDP/PLR) } \\
\hline & \multicolumn{2}{|c|}{$\begin{array}{l}\text { Model 1: Votes } \\
\text { from own lists }\end{array}$} & \multicolumn{2}{|c|}{$\begin{array}{c}\text { Model 2: } \\
\text { Panachage votes }\end{array}$} & \multicolumn{2}{|c|}{$\begin{array}{l}\text { Model 1: Votes } \\
\text { from own lists }\end{array}$} & \multicolumn{2}{|c|}{$\begin{array}{c}\text { Model 2: } \\
\text { Panachage votes }\end{array}$} \\
\hline & Coef. & SE & Coef. & SE & Coef. & SE & Coef. & SE \\
\hline \multicolumn{9}{|l|}{ Leading positions } \\
\hline Trade Union & \multicolumn{2}{|c|}{ (omitted) } & \multicolumn{2}{|c|}{ (omitted) } & -0.35 & 0.34 & -0.36 & 0.66 \\
\hline Business & 0.14 & 0.15 & -0.06 & 0.27 & -0.12 & 0.10 & -0.37 & $0.21^{*}$ \\
\hline Professional & -0.17 & 0.20 & 0.14 & 0.36 & 0.08 & 0.09 & 0.39 & $0.17 * *$ \\
\hline Identity & -0.27 & 0.21 & -0.14 & 0.39 & -0.01 & 0.09 & -0.21 & 0.18 \\
\hline Sport/Leisure & 0.16 & $0.10^{*}$ & 0.06 & 0.17 & 0.01 & 0.09 & -0.17 & 0.17 \\
\hline Public Interest & -0.05 & 0.13 & -0.10 & 0.24 & 0.11 & 0.07 & 0.08 & 0.13 \\
\hline Firm & 0.02 & 0.16 & 0.11 & 0.28 & 0.09 & 0.10 & 0.64 & $0.21^{* * *}$ \\
\hline \multicolumn{9}{|l|}{ Endorsements } \\
\hline Trade Union & \multicolumn{2}{|c|}{ (omitted) } & \multicolumn{2}{|c|}{ (omitted) } & \multicolumn{2}{|c|}{ (omitted) } & \multicolumn{2}{|c|}{ (omitted) } \\
\hline Business & 0.07 & 0.15 & 0.24 & 0.26 & 0.11 & 0.10 & 0.27 & 0.20 \\
\hline Professional & 0.38 & $0.17 *$ & 0.19 & 0.31 & -0.10 & 0.10 & -0.08 & 0.21 \\
\hline Identity & 0.47 & 0.36 & 0.66 & 0.64 & -0.07 & 0.10 & 0.08 & 0.21 \\
\hline Sport/Leisure & 0.05 & 0.17 & -0.20 & 0.30 & 0.09 & 0.14 & 0.13 & 0.27 \\
\hline Public Interest & -0.02 & 0.11 & 0.08 & 0.20 & 0.24 & $0.12 * *$ & 0.59 & $0.23 * * *$ \\
\hline Firm & 0.12 & 0.43 & 0.16 & 0.75 & -0.11 & 0.35 & -0.31 & 0.67 \\
\hline Gender (female) & 0.33 & $0.12 * * *$ & 0.57 & $0.22 * *$ & -0.04 & 0.06 & 0.03 & 0.12 \\
\hline Age & -0.01 & $0.00 * *$ & 0.00 & 0.01 & 0.00 & 0.00 & 0.00 & 0.01 \\
\hline Year in party & 0.00 & 0.01 & 0.01 & 0.01 & 0.01 & 0.00 & 0.01 & 0.01 \\
\hline $\begin{array}{l}\text { Holding local } \\
\text { party office }\end{array}$ & 0.19 & $0.09 *$ & 0.10 & 0.16 & -0.15 & $0.06^{* *}$ & -0.28 & $0.13 * * *$ \\
\hline $\begin{array}{l}\text { Holding national } \\
\text { party office }\end{array}$ & 0.10 & 0.12 & 0.09 & 0.22 & 0.16 & 0.10 & 0.35 & $0.20 * * *$ \\
\hline Constant & -0.36 & $0.14 * * *$ & -1.18 & $0.33 * * *$ & -0.47 & $0.08 * * *$ & -0.61 & $0.24 * * *$ \\
\hline Random effects (s.d.) & 0.48 & 0.075 & 1.47 & 0.19 & 0.28 & 0.05 & 1.28 & 0.15 \\
\hline Residuals (s.d) & 0.34 & 0.029 & 0.58 & 0.05 & 0.27 & 0.02 & 0.51 & 0.04 \\
\hline $\mathrm{N}$ (candidates) & 199 & & 116 & & 151 & & 151 & \\
\hline $\mathrm{N}$ (lists) & 55 & & 41 & & 47 & & 47 & \\
\hline
\end{tabular}

$* \mathrm{p} \leq .05 * * \mathrm{p} \leq .01 * * * \mathrm{p} \leq .001$

might be deciding factors for FDP/PLR candidates who are only partially captured by our measurement. ${ }^{10}$ Endorsements from public interest groups also positively affect votes from their own lists and panachage votes for FDP/PLR candidates.

Overall, we do not find much support for hypothesis 5 concerning the effect of support from business associations, professional groups and firms for candidates from right-wing parties. For candidates from right-wing parties, other features seem to be more important in attracting preference votes than interest group ties for this type of organization. The results for the FDP/PLR candidate provide a confirmation of hypothesis 4, which assumes a positive effect of support from public interest groups. Even among right-wing voters, support from public interest groups has a greater impact on electoral success than support from business associations and professional groups.

\footnotetext{
${ }^{10}$ For an exploration of this aspect, see Mechtel (2014).
} 


\section{Conclusions}

This paper's goal was to shed some light on the nature and importance of the relationships between interest groups and candidates running for elections and the impact of these ties on electoral success. While the inter-relations between members of parliament and interest groups have been subjects of public debate for some time, the way they play out during electoral campaigns has not been thoroughly explored.

A few results stand out. Our analysis allowed us to highlight the relevance of public interest groups not only in policy processes (Gava et al. 2017), but also during the electoral campaign. We could show, overall, that public interest groups are particularly important for candidates, more so than traditional corporatist actors, at least according to candidates' responses to the CCS 2015. The great quantity of formal ties and ad-hoc active support reported by candidates with this group type-and from all parties, moreover-and the consistency of this result with regard to leading positions and endorsements show that this group type has become important and effective during electoral campaigns as well. Moreover, it is the only interest group type that has a systematic impact on electoral success. Public interest groups generate larger electoral support than sectional groups, such as business interest groups or professional groups. The same is not true for other group types, but the partial confirmation of our hypotheses shows that support is also linked, in some cases, to close traditional connections between interest groups and parties.

Overall, this paper provides us exploratory information confirming the effect of interest group support on candidate success. Interest group linkage increases some candidates' chances of receiving preference votes, but the positive effect hinges on holding leading positions - that is, being well rooted in the interest group - and endorsements, meaning on the public visibility of ties and support and not so much on financial support, which seems rare in any case. The results also show variation in how different forms of support from different interest groups matter for candidates from the different parties.

What matters for candidates is to stand out compared to other candidates on the same list. The mechanism how ties to interest groups are relevant for candidates is, however, complex. If an entire party is identified with certain interest groups, the positive effect on electoral success for candidates with strong ties to such interest groups seems to be more limited compared to cases where a link to an interest group is not the norm within a party.

These results must be nuanced by taking the following limitations into account. Very limited information is available regarding the lack of influence of financial contributions on individual candidates from interest groups. We do not have information on how much money candidates receive from specific interest groups since such disclosure is not required in Switzerland. So, the absence of a measurable influence could also be related to the weak data available. We also rely on candidates' self-declarations regarding the support they received from interest groups. Some candidates may not have reported this accurately, either on purpose or because they have forgotten about it. We have further excluded all incumbent candidates from the analysis because reversed causality could apply for them: Not only would ties and support explain their electoral success, but their incumbent status would explain the support received.

Despite these limitations, the evidence provided by our data reveals the existence of the effect of interest group support on electoral success. It also introduces the possibility for further analysis on individual data to assess the impact of interest group support on the electoral success of candidates. 


\section{References}

Allern, E. and T. Bale (2012). Political Parties and Interest Groups: Disentangling Complex Relationships. Party Politics 18(1): 7-25.

Austen-Smith, D. (1987). Interest Groups, Campaign Contributions, and Probabilistic Voting. Public Choice 54(2): 123-139.

Baumgartner, F.R., J.M. Berry, M. Hojnacki, B.L. Leech and D.C. Kimball (2009). Lobbying and Policy Change: Who Wins, Who Loses, and Why. Chicago: University of Chicago Press.

Bigelow, N. and P. Herrnson (2008). Interest Group Activity in U.S. Elections. In Farrell, D. and R. Schmitt-Beck (eds.), Non-Party Actors in Electoral Politics. The Role of Interest Groups and Independent Citizens in Contemporary Election Campaigns. Baden-Baden: Nomos Verlagsgesellschaft (45-66).

Bühlmann, M., D. Zumbach, M. Gerber and A. Heidelberger (2016). Cherry Picking at the 2015 Swiss Federal Elections: The Influence of Electoral Campaigning on Panachage and Cumulation. Paper presented at the ECPR General Conference, Prague.

Carson, J., E. Engstrom and J. Roberts (2007). Candidate Quality, the Personal Vote, and the Incumbency Advantage in Congress. American Political Science Review 101(2): 289-301.

Eichenberger, S. and A. Mach (2017). Formal Ties between Interest Groups and Members of Parliament: Gaining Allies in Legislative Committees. Interest Groups \& Advocacy 6(1): $1-21$.

Engeli, I. and G. Lutz (2014). When Women Run and Campaign, Do They Win?. Paper presented at the ECPR Joint Session, Salamanca.

Erne, R. and S. Schief (2016). Strong Ties Between Independent Organizations. Unions and Political Parties in Switzerland. In Allern, E. and T. Bale (eds.), Left-of-Centre Parties in the Twenty-First Century. Oxford: Oxford University Press (226-245).

Farrell, D. and R. Schmitt-Beck (eds.) (2002). Do Political Campaigns Matter? Campaign Effects in Elections and Referendums. London: Routledge.

Farrell, D. and R. Schmitt-Beck (eds.) (2008). Non-Party Actors in Electoral Politics. The Role of Interest Groups and Independent Citizens in Contemporary Election Campaigns. Baden-Baden: Nomos Verlagsgesellschaft.

Gava, R., F. Varone, A. Mach, S. Eichenberger, J. Christe and C. Chao-Blanco (2017). Interest Groups in Parliament: Exploring MPs' Interest Affiliations (2000-2011). Swiss Political Science Review 23(1): 77-94.

Grossman, G. and E. Helpman (1996). Electoral Competition and Special Interest Politics. The Review of Economic Studies 63(2): 265-286.

Gruner, E. and J. Siegenthaler (1964). Die Wahlen in die eidgenössischen Räte im Oktober 1963. Jahrbuch der Schweizerischen Vereinigung für Politische Wissenschaft 4: 113-153.

Gruner, E., M. Dätwyler and O. Zosso (1975). Aufstellung und Auswahl der Kandidaten bei den Nationalratswahlen in der Schweiz am Beispiel der Wahlen von 1971. Bern: Forschungszentrum für Schweizerische Politik.

Gruner, E. (1977). Die Parteien in der Schweiz. Bern: Francke.

Karvonen, L. (2010). The Personalization of Politics. A Study of Parliamentary Democracies. Colchester: ECPR Press.

Lachat, R. and P. Sciarini (2002). When Do Election Campaigns Matter, and to Whom? Results from the 1999 Swiss Election Panel Study. In Farrell, D. and R. Schmitt-Beck (eds.), Do Political Campaigns Matter? Campaign Effects in Elections and Referendums. London: Routledge (41-57). 
Ladner, A. (2015). Bottom-up Parties and Interest Groups with Strong Integrative Tendencies. In Detterbeck, K., W. Renzsch and J. Kincaid (eds.), Political Parties and Civil Society in Federal Countries. Don Mills: Ontario Oxford University Press (254-278).

Lutz, G. (2010a). The Electoral Success of Beauties and Beasts. Swiss Political Science Review 16(3): 457-480.

- (2010b). First Come, First Served: The Effect of Ballot Position on Electoral Success in Open List PR Elections. Representation 46(2): 167-181.

- (2016). Eidgenössische Wahlen 2015. Wahlteilnahme und Wahlentscheid. Selects/FORS: Lausanne

McDermott, M. (2006). Not for Members Only. Group Endorsements as Electoral Informational Cues. Political Research Quarterly 59(2): 249-257.

McKay, A. (2018). What Do Campaign Contributions Buy? Lobbyists' Strategic Giving. Interest Groups \& Advocacy 7(1): 1-18.

Mechtel, M. (2014). It's the Occupation, Stupid! Explaining Candidates Success in Low-Information Elections. European Journal of Political Economy 33: 53-70.

Pilotti, A. (2017). Entre démocratisation et professionalisation: le Parlement suisse et ses membres de 1910 à 2016. Zurich, Geneva: Seismo.

Poguntke, T. (2006). Political Parties and Other Organizations. In Katz, R. and W. Crotty (eds.), Handbook of Party Politics. London: Sage (396-405).

Potters, J. and R. Sloof (1996). Interest groups: A Survey of Empirical Models That Try to Assess Their Influence. European Journal of Political Economy 12(3): 403-442.

Rahat, G. (2008). Entering through the Back Door: Non-Party Actors in Intra-Party (S)electoral Politics. In Farrell, D. and R. Schmitt-Beck (eds.) (2008), Non-Party Actors in Electoral Politics. The Role of Interest Groups and Independent Citizens in Contemporary Election Campaigns. BadenBaden: Nomos Verlagsgesellschaft.

Rasmussen, A. and G. Lindeboom (2013). Interest Group-Party Linkage in the Twenty-First Century: Evidence from Denmark, the Netherlands and the United Kingdom. European Journal of Political Research 52(2): 264-289.

Selb, P. and G. Lutz (2014). Lone Fighters: Intraparty Competition, Interparty Competition, and Candidates' Vote Seeking Efforts in Open-Ballot PR Elections. Electoral Studies 39: 329-337.

Schwindt-Bayer, L.A., M. Malecki and B.F. Crisp (2010). Candidate Gender and Electoral Success in Single Transferable Vote Systems. British Journal of Political Science 40(3): 639-709.

Stratmann, T. (2005). Some Talk: Money in Politics. A (Partial) Review of the Literature. Public Choice 124(1/2): 135-156.

Weber, C., J. Donaway and T. Johnson (2012). It's All in the Name: Source Cue Ambiguity and the Persuasive Appeal of Campaign Ads. Political Behavior 34(3): 561-584.

Weiler, F. and M. Brändli (2015). Inside Versus Outside Lobbying: How the Institutional Framework Shapes the Lobbying Behaviour of Interest Groups. European Journal of Political Research 54(4): 745-766.

Wiesli, R. (2003). Switzerland: The Militia Myth and Incomplete Professionalization. In Borchert, J. (ed.), The Political Class in Advanced Democracies. Oxford: Oxford University Press (374-392).

Georg Lutz is Associate Professor at the University of Lausanne, Institute of Political, Historical and International Studies and Director of the Swiss Foundation for Research in Social Sciences (FORS). His fields of specialization include political behavior, political institutions, electoral systems and political participation. Email: georg.lutz@fors.unil.ch. 
André Mach is Associate Professor at the University of Lausanne, Institute of Political, Historical and International Studies. His fields of specialization include elite studies, interest groups and comparative political economy. Email: andre.mach@unil.ch.

Riccardo Primavesi is a SNSF PhD candidate at the University of Lausanne, Institute of Political, Historical and International Studies. His fields of specialization include interest group sociology and comparative political economy. Email: riccardo.primavesi@unil.ch. 